\title{
A Legislação Trabalhista no Brasil (1964-1988)
}

\author{
Hugo G. de Faria*, Fernando T. da Silva
}

\section{Resumo}

A presente pesquisa vincula-se a um projeto temático da FAPESP, a partir do qual realizou a inserção de normas legais referenciadas pela historiografia sobre o trabalho e os trabalhadores no Brasil entre 1964 e 1988, em uma Base de Dados chamada "Legislação: Trabalhadores e Trabalho em Portugal, Brasil e África Colonial Portuguesa" construída coletivamente pelo Centro de Pesquisa em História Social da Cultura - CECULT/UNICAMP. A proposta conjuga-se a um trabalho de pesquisa individual no qual foi desenvolvida uma reflexão sobre os posicionamentos da Federação das Indústrias do Estado de São Paulo (FIESP) na Assembleia Nacional Constituinte (1987-1988) em torno da polêmica acerca da primazia do negociado sobre o legislado que se localiza na temática da legislação trabalhista e das negociações coletivas.

\section{Palavras-chave: \\ Assembleia Nacional Constituinte; Fiesp; Legislação Trabalhista;}

\section{Introdução}

O projeto inicial de pesquisa estabeleceu como objetivos realizar: 1) Um trabalho coletivo de pesquisa empírica junto ao banco de dados; 2) Um levantamento bibliográfico sobre o tema de pesquisa individual; 3) Leituras bibliográficas e discussões teóricas da pesquisa individual; 4) Análise das fontes primárias; 5) Confecção dos relatórios parcial e final de pesquisa. Durante o primeiro semestre do projeto, participei da construção da referida base de dados em uma etapa que consistiu num grande esforço prático e teórico ao tratar diretamente da documentação dos mais variados assuntos legais referentes à relação entre capital e trabalho. Já no segundo semestre de pesquisa o trabalho junto à base de dados foi concluído, passando à pesquisa individual referente aos posicionamentos da principal organização patronal do país, a Federação das Industrias do Estado de São Paulo - FIESP, em torno da prevalência do negociado sob o legislado, aspecto central da alternativa neoliberal que se consolidou na década de 1990 no país, mas que se caracterizou durante os debates da Assembleia Nacional Constituinte (1987-1988). A pesquisa voltou-se então neste segundo momento à analise das fontes primárias, que já se encontravam préselecionadas. Das que foram estabelecidas inicialmente, procedi a análise da Revista da Indústria, dado a expressividade do periódico para os objetivos da pesquisa. Por fim, o objetivo do projeto em seu relatório final é apresentar um balanço amplo dos posicionamentos da entidade patronal sobre as controvérsias durante a Assembleia Nacional Constituinte que envolvem a prevalência do negociado sob 0 legislado, a legislação trabalhista e a negociação coletiva. Tal balanço será apresentado em conjunto com o debate teórico desenvolvido, a fim de situar conceitualmente, historicamente e sistematicamente a análise e os resultados obtidos a partir das fontes primárias.

\section{Resultados e Discussão}

Com relação aos objetivos específicos estipulados no projeto inicial, o trabalho coletivo de pesquisa empírica referente à coleta, sistematização e inserção das legislações no banco de dados foi o foco do primeiro semestre, assim como o levantamento bibliográfico realizado durante as reuniões regulares com 0 orientador. No segundo semestre, a pesquisa focou no desenvolvimento individual, na dimensão teórica e na análise empírica das fontes primárias, que serão apresentados de forma articulada no relatório final de pesquisa visando a sistematização conceitual e histórica dos resultados obtidos.

\section{Conclusões}

A conclusão preliminar da pesquisa é de que os posicionamentos da entidade patronal sobre a questão do negociado sobre o legislado apontaram de forma geral para restrição da ação estatal e defesa do "livre mercado". De forma mais específica, destaco as defesas da estabilidade no emprego como assunto de negociação coletiva e do incentivo aos mecanismos de justiça privada, assim como a arbitragem. Destaca-se também a relação entre legislação trabalhista e a estrutura sindical, tendo em vista a defesa da contribuição sindical como necessária ao financiamento das entidades de classe e consequentes sucessos em negociações diretas.

\section{Agradecimentos}

Agradeço aos profissionais do Centro de Pesquisa em História Social da Cultura - CECULT/UNICAMP pelo apoio à pesquisa e ao PIBIC pelo aporte financeiro.

BIANCHI, Álvaro. Um Ministério dos Industriais: A Federação das Indústrias do Estado de São Paulo na crise das décadas de 1980 e 1990. Campinas: Editora UNICAMP, 2010.

CARDOSO, Adalberto Moreira. A década neoliberal: e a crise dos sindicatos no Brasil. São Paulo: Boitempo, 2003.

COSTA, L.; TROIANO, M. Uma análise das atuações do Diap e da Fiesp sob a ótica da teoria institucional. Revista eletrônica dos alunos da Escola de Sociologia e Política de São Paulo, São Paulo, ano 4, v. 2, n. 8, 2016.

DREIFUSS, R. O jogo da direita. Petrópolis: Vozes, 1989. FIESP. Revista da indústria. São Paulo, 1987. 